Acta horticulturae et regiotecturae 2

Nitra, Slovaca Universitas Agriculturae Nitriae, 2013, s. 33-36

\title{
COPPER IN THE SEDIMENTS IN SELECTED BANSKÁ ŠTIAVNICA WATER RESERVOIRS MED̆ V SEDIMENTOCH VO VYBRANÝCH BANSKO-ŠTIAVNICKÝCH VODNÝCH NÁDRŽIACH
}

\author{
Jana URMINSKÁ, Peter ONDRIŠÍK, Renáta PROKEINOVÁ \\ Slovak University of Agriculture in Nitra, Slovak Republic
}

\begin{abstract}
The aim of this paper was to analyze and evaluate sediments of selected water reservoirs Počúvadlo, Malá Richňava, Velká Richňava, Windšachta, in order to determine the concentrations of copper in the monitored water reservoirs in the Banská Štiavnica region. The analyses of the sediment samples were carried out by flow electrochemistry and atomic absorption spectrometry. In the study area, the samples were collected from 2001 to 2010; we found the following concentrations of copper in the range from $1.66 \mathrm{mg} \cdot \mathrm{kg}^{-1}$ to $14.0 \mathrm{mg} \cdot \mathrm{kg}^{-1} \mathrm{Cu}$ of dry matter. The copper concentrations in the sediments were well below the risk limit according to "The Methodological Instruction of the Ministry of Environment of the Slovak Republic no. 549/98-2". Based on the calculated dependency index, it is possible to assess the development of changes in the concentrations over the years as highly dynamic, and unsatisfactory for natural environment.
\end{abstract}

Keywords: Banská Štiavnica, copper, sediment, water reservoirs

Sediment is a special and dynamic system. In this medium, there are intensive biological and chemical-physical changes due to the actions of various natural and anthropogenic factors (Peng et al., 2009). Anthropogenic parts of sediments are formed as parts of flushes and by sedimentation of ambient material, and by potential atmospheric deposition (Fang et al., 2005). Contamination of sediments in Banská Štiavnica water reservoirs has been associated with mining activities, focused on ore mining. The most important reservoirs in the Banská Štiavnica water management system are in the Piarg group (Lichner et al., 2005). These water reservoirs are contaminated by multiple sources of geogenic and anthropogenic origin; especially mining and industrially activities are located in various parts of catchment environment. Currently, the subject area is heavily used for recreational purposes and agricultural tourism.

\section{Copper in the selected environment}

Distribution of copper in the sediments of the Slovak Republic is conditioned by contrast of its contents in source rocks, occurrence of ore mineralization; anthropogenic distribution into the environment, having a major and full area impact, is also of importance, particularly because of its application in agriculture. The average copper concentration in the sediments of the Slovak Republic is $32 \pm$ $133 \mathrm{mg} \cdot \mathrm{kg}^{-1}$. The biggest copper anomaly in the range from 43 to 206 mg. kg ${ }^{-1}$ is located in the fields of Gemericum and Veporicum. In the area of the Central Neovolcanit rocks also reach high concentrations. The lowlands and intermountain depressions are linked to the zones with copper contents in the sediments higher than average (31-69 mg. $\left.\mathrm{kg}^{-1}\right)$. There are carried out intensive agricultural activities, for example spraying with copper sulphate (Bodiš a Rapant, 1999). Copper in sediments has a positive correlation $(p>0.4)$ with $\mathrm{As}, \mathrm{Hg}, \mathrm{Zn}, \mathrm{Cd}, \mathrm{Fe}_{2} \mathrm{O}_{3}$, low correlation with $(p>0.3)$ $\mathrm{P}_{2} \mathrm{O}_{5}, \mathrm{~Pb}, \mathrm{Ti}$ and $\mathrm{Ga}$, Fe (Salminen et al., 2005). Its relation with the elements $\mathrm{As}, \mathrm{Hg}, \mathrm{Zn}, \mathrm{Cd}, \mathrm{Pb}$ and $\mathrm{P}_{2} \mathrm{O}_{5}$ suggests that geochemical processes, petrography and mineralization are important factors influencing the distribution of copper (Salminen et al., 2005).

The aim of our research was to analyze and evaluate the sediments of the selected water reservoirs of the Piarg group - Počúvadlo, Malá Richňava, Vel'ká Richňava, Windšachta. We also strive to determine the concentrations of copper in the sediments, and to evaluate potential riskiness of its impact on the environment in the years 2001-2010.

\section{Material and methods}

The evaluation of the environment quality was based on terrain observations of the region Banská Štiavnica, laboratory analyses of sediments of the selected artificial water reservoirs in the study area and consequently, the data were statistically processed. The focus of the data consisted in sediment quality assessment by "The Methodological Instruction of the Ministry of Environment of the Slovak Republic no. 549/98-2 for risk assessment of contaminated sediment flows and water reservoirs" based on the concentration of potentially toxic elements i. e. also copper. For statistical processing, "Spearman's correlation coefficient" (Stehlíková, 1999) and "Index analysis" (Obtulovič, 2010) methods were used. Collecting samples submerged under water in the selected reservoirs was realised annually in autumn. The sediments were taken from the dam sediment and the sediment located opposite the dam. Each sample represented 5 intakes from one sampling point. The material was put together in pure polyethylene 
containers. The samples assigned to chemical element detection were carefully stored in PVC bags and kept frozen for further processing and analysis. To determine the total content of the contaminant, we used the sediment fractionation with grain size less than $0.125 \mathrm{~mm}$. The analyses of the sediment samples were carried out (certificate no. $01871 / 101 / 1 / 2001$ ) by the flow electrochemistry method and the atomic absorption spectrometry method.

\section{Results and discussion}

According to the results of chemical analysis of copper concentration in the sediments in 2001 to 2010, we measured values from $1.66 \mathrm{mg} \cdot \mathrm{kg}^{-1}$ to $14.0 \mathrm{mg} \cdot \mathrm{kg}^{-1}$ of dry matter. The concentrations of copper in the sediments were well below the risk limit (limit for $\mathrm{Cu}$ is $73.0 \mathrm{mg} \cdot \mathrm{kg}^{-1}$ ) according to "The Methodological Instruction of the Ministry of Environment no. 549/98-2".

"Index analysis" is an analysis of phenomena and processes that we want to evaluate in terms of the dynamics

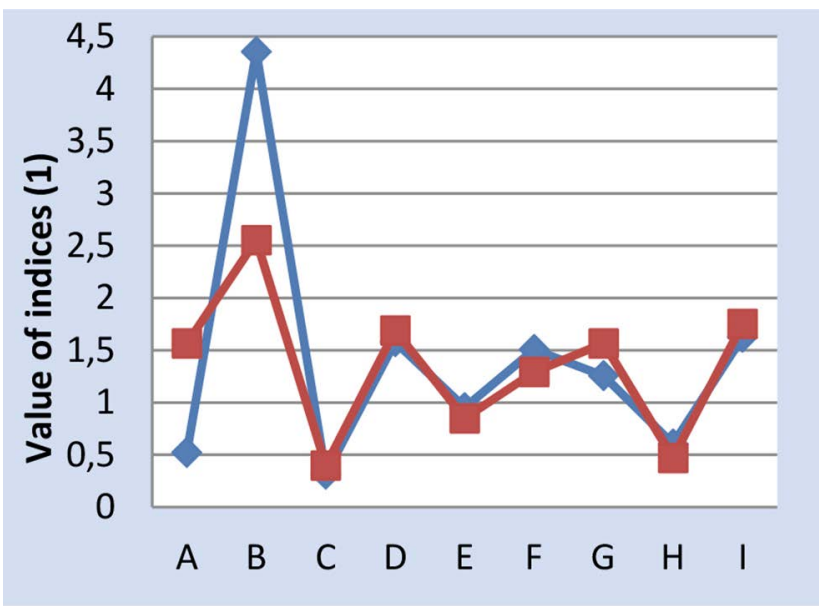

a) Počúvadlo

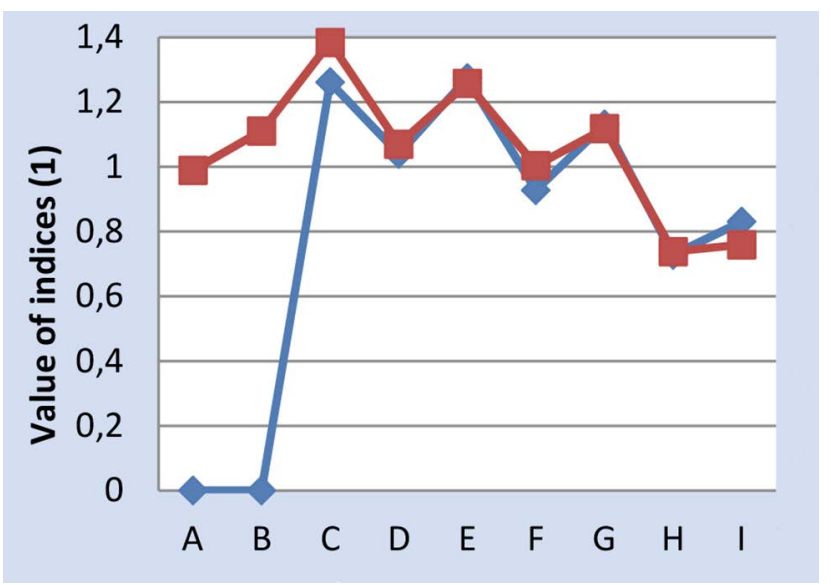

b) Malá Richňava of their development, comparable indicators in time and space, and in terms of substantive definition (Obtulovič, 2010). Dependence development of average copper concentrations in the locations compared in the years 2001-2010 showed a very high dynamics (Fig. 1a-d). The dynamics could be caused by significant anthropogenic activities, local hydrometeorological and changing thermodynamic conditions, as confirmed by Hiller et al. (2010). The most significant extreme value indices were calculated for the water reservoir Počúvadlo in year 2004 from the dam sampling point with the decrease of $68.44 \%$ compared to 2003 and the increase by up to $335.63 \%$ in 2003 compared to 2002. Malá Richňava marked different values compared to the other monitored lakes in 2009 with a decline of $27.22 \%$ in comparison with 2008 in the dam sampling point and the sampling point opposite the dam with an increase of $38.44 \%$ in 2004 compared to 2003. Extreme value indices for Vel'ká Richňava were calculated in 2005 from the sampling point opposite the dam, where there was a decrease by $48.60 \%$ compared to 2004 and 2003; the dam sampling point with an increase of $230.42 \%$

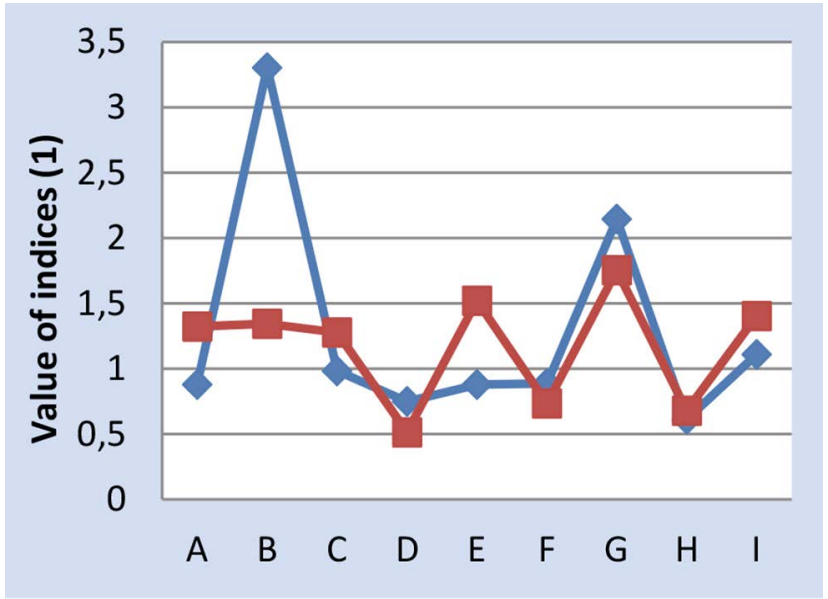

c) Vel'ká Richňava

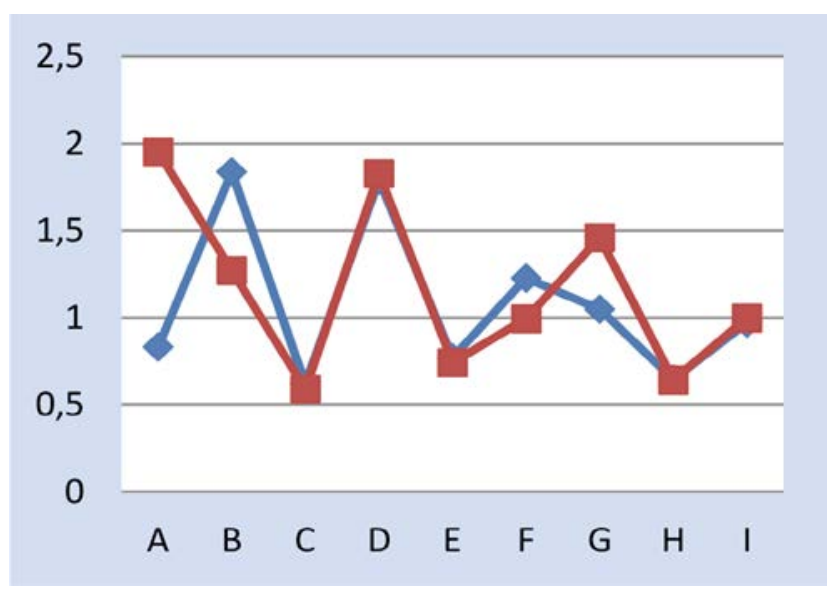

d) Windšachta

Figure 1 Value of indices for copper

dam sampling points (2), opposite the dam sampling points (3)

A - years (4) 2002/2001, B - 2003/2002, C - 2004/2003, D- 2005/2004, E- 2006/2005, F-2007/2006, G - 2008/2007, H- 2009/2008, I- 2010/2009

Obrázok 1 Hodnoty indexov pre med'

(1) hodnota indexu, (2) odber vzoriek z hrádze, (3) odber vzoriek oproti hrádzi, (4) roky 
compared to 2002. For Windšachta, we calculated index values in 2004 with a decrease of $41.01 \%$ compared to 2003 from the sampling point opposite the dam and in 2002 from the same sampling point compared to 2001 with an increase by $95.07 \%$. Generally, for all the observed sampling sites and years there was an increase in the percentage values. Based on the calculated dependency ratio, we can evaluate the development as highly dynamic and very negative for the environment.

Spearman's correlation coefficient $\rho_{s}$ is a measure of dependence, based on the measurement of dependence between rankings (Stehlíková, 1999). Based on the statistical analysis of the results it can be stated that copper showed very high correlation significance in relations to lead, arsenic and cadmium, and high significance for zinc and mercury (the concentrations of the observed chemical elements are listed in the Urminská, 2011). It can be supposed that increasing concentrations of the first listed chemical element support a substantial increase in the contents of the compared ones. All the calculated correlations showed positive dependences.

Positive dependence and clear significance for $\mathrm{Cu}: \mathrm{Pb}$ and other elements are documented by

Hiller et al (2010). The concentrations of the chemical elements and their mutual correlations were observed in water reservoirs in Vel'ké Kozmálovce and Ružín. The analytically detected concentrations of copper in the sediments were below the threshold limit risk. However, this accumulated material is contaminated with other dangerous elements like cadmium, mercury or lead (Urminská, 2011). This sediment and its potentially toxic elements must undergo ex situ decontamination using chemical extraction, solidification or bacterial elimination methods. Many studies have confirmed that the contaminated sediments are contributing to environmental degradation. And in principle, they are considered one of the greatest sources of contaminants (Královec a Slavík, 1997). They become sources of hazardous contaminants such as $\mathrm{Cd}, \mathrm{Pb}, \mathrm{As}, \mathrm{Hg}, \mathrm{Cu}, \mathrm{Cr}^{6+}$ and $\mathrm{Zn}$. Risk concentrations of potentially toxic elements are the results of intensive mining activities, metallurgy, agricultural activities, anthropogenic and diverse urban activities. Subsequently, the sediments possess anomalous geochemical and chemical concentrations (Kishe et al., 2003; Liu et al., 2005; Duman, Aksoy and Demirezen, 2007; Liu et al., 2008; Mishra et al., 2008; Tang et al., 2008; Hiller et al., 2010; Wei et al., 2010).

\section{Conclusion}

The samples from lake sediments in the area of Banská Štiavnica contained many chemical elements. The concentration of copper did not exceed the maximum limit in the selected Piarg water reservoirs according to "The Methodological Instruction of the Ministry of Environment of the Slovak Republic no. 549/98-2 for risk assessment of contaminated sediment flows and water reservoirs". Generally, there were increases in the percentage values for all observed sampling sites and years. Based on the calculated dependency ratio, the development can be labelled as highly dynamic and very negative for the environment. According to Spearman's correlation coefficient, there are very highly significant relations between copper and arsenic, cadmium and lead. From statistical processing of data we had detected that dependency of $\mathrm{Cu}$ to other elements $(\mathrm{Pb}, \mathrm{As}, \mathrm{Cd})$ is very high and as a result it can be stated that where there is an increase of copper concentration in the environment, there are also spotted higher accumulations of the second (dependent) element.

\section{Súhrn}

Cielom článku bolo analyzovat' a zhodnotit' sedimenty vybraných vodných nádrží Počúvadlo, Malá Richňava, Vel'ká Richňava, Windšachta, stanovit' koncentrácie medi v týchto sedimentoch a zhodnotit' rizikovost' vplyvu tohto prvku vyskytujúceho sa $v$ sedimentoch sledovaných vodných nádrží bansko-štiavnického regiónu v rokoch 2001 až 2010 na životné prostredie. Analýza výluhov vzoriek sedimentov bola uskutočnená princípom prietokovej elektrochémie a metódou atómovej absorpčnej spektrometrie. Zo získaných výsledkov vyplynulo, že med' bola prítomná v koncentráciách 1,66 - 14,0 mg.kg-1 suchej hmoty. Stanovené koncentrácie medi v sedimente boli pod rizikovou limitnou hranicou podla hodnotenia na základe "Metodického pokynu MŽP SR 549/98-2“. Na základe vypočítaných indexov závislostí je možné hodnotit’ vývoj zmien koncentrácií ako vysoko dynamický, pre prírodné prostredie nevyhovujúci.

Klúčové slová: Banská Štiavnica, med', sediment, vodné nádrže

\section{References}

BODIŠ, D. - RAPANT, S. 1999. Geochemický atlas Slovenskej republiky. Čast' Vl.: Riečne sedimenty, Mierka 1: 1000 000. Bratislava: MŽP SR a GSSR, 1999, 145 s. ISBN 80-88833-18-3.

DUMAN, F. - AKSOY, A. - DEMIREZEN, D. 2007. Seasonal variability of heavy metals in surface sediment of Lake Sapanca, Turkey. In: Environmental Monitoring \& Assessment, vol. 133, 2007, no. 1-3, pp. 277-283.

FANG, T. - LIU, J. - XIAO, B. - CHEN, X. - XU, X. 2005. Mobilization potential of heavy metals: A comparison between river and lake sediments. In: Water, Air \& Soil Pollution, vol. 161, 2005, no. 1-4, pp. 209-225.

HILLER, E. - JURKOVIČ, L. - ŠUTRIEPKA, M. 2010. Metals in the surface sediments of selected water reservoirs, Slovakia. In: Bulletin of Enironmental Contamination and Toxicology, 84, 2010, pp. 635640. ISSN 0007-4861.

KISHE, M. A. - MACHIWA, J. F. 2003. Distribution of heavy metals in sediments of Mwanza Gulf of Lake Victoria, Tanzania. In: Environment International, vol. 28, 2003, no. 7, p. 619.

KRÁLOVEC, J. - SLAVÍK, L. 1997. Přenos olova, kadmia a rtuti v systému půda - rostlina - zviŕe. In: Rostlinná výroba, č. 43,1997, s. 257-262.

LICHNER, M. et al. 2005. Banskoštiavnické tajchy. Banská Bystrica : Harmony, 2005, 127 s. ISBN 80-89151-08-6.

LIU, E. - SHEN, J. - LIU, X. 2005. Geochemical features of heavy metals in core sediments of northwestern Taihu Lake, China. In: Chinese Journal of Geochemistry, vol. 24, 2005, no. 1, pp. 73-81.

LIU, H. - LI, L. - YIN, CH. - SHAN, B. 2008. Fraction distribution and risk assessment of heavy metals in sediments of Moshui Lake. In: 
Journal of Environmental Sciences (Elsevier), vol. 20, 2008, no. 4, pp. 390-397.

METHODOLOGICAL INSTRUCTION of the Ministry of Environment the Slovak republic no. 549/98-2 for risk assessment of contaminated sediment flows and water reservoirs.

MISHRA, V. K. - UPADHYAY, A. R. - PANDEY, S. K. - TRIPATHI, B. D. 2008. Concentrations of heavy metals and aquatic macrophytes of Govind Ballabh Pant Sagar an anthropogenic lake affected by coal mining affluent. In: Environmental Monitoring \& Assessment, vol. 141, 2008, no. 1-3, pp. 49-58.

OBTULOVIČ, P. 2010. Bioštatistika. Nitra : SPU, 2010, s. 139-141. ISBN 978-80-552-0397-3.

PENG J. F. - SONG, Y. H. - PENG, Y. - CUI, X. - QIU, G. 2009. The remediation of heavy metals contaminated sediment. In: Journal of Hazardous Materials, vol. 161, 2009, no. 2/3, pp. 633-640. ISSN 0304-3894.

SALMINEN, R. et al. 2005. Geochemical Atlas of Europe. Part 1 - Background Information, Methodology and Maps. Brussels : EuroGeoSurveys Belgium, 2005, 525 p.

STEHLÍKOVÁ, B. 1999. Biometrika (Terminologický slovník). Učebné texty pre dištančné štúdium a ostatné formy vzdelávania. Nitra : SPU, 1999, $95 \mathrm{~s}$.
TANG, CH.W. - IP, C. CH. - ZHANG, G. - SHIN, P. K. S. - QIAN, P. - LI, X. 2008. The spatial and temporal distribution of heavy metals in sediments of Victoria Harbour, Hong Kong. In: Marine Pollution Bulletin, $5^{\text {th }}$ International Conference on Marine Pollution and Ecotoxicology, vol. 7, 2008, no. 6-12, pp. 816-825.

URMINSKÁ, J. 2011. Riziko vplyvu vybraných t’ažkých kovov v sedimentoch sledovaných bansko-štiavnických vodných nádrží na životné prostzredie. Habilitačná práca, Katedra environmentalistiky a zoológie, Nitra : SPU, 2011, $177 \mathrm{~s}$.

WEI, M. R. - JIANG, Y. H. - ZHAO, W. Y. - JIANG, C. F. - LONG, M. F. 2010. Heavy Metals Pollution Assessment of Surface Sediment in Dananhu Lake. In: Guilin Gongxueyuan Xuebao/Journal of Guilin University of Technology, vol. 30, 2010, no. 3, pp. 415-418.

\section{Contact address:}

doc. RNDr. Jana Urminská, PhD., Slovak University of Agriculture in Nitra, Faculty of Agrobiology and Food Resources, Department of Environment and Zoology, Tr. Andreja Hlinku 2, 94976 Nitra, Slovakia, e-mail: Jana. Urminska@uniag.sk 